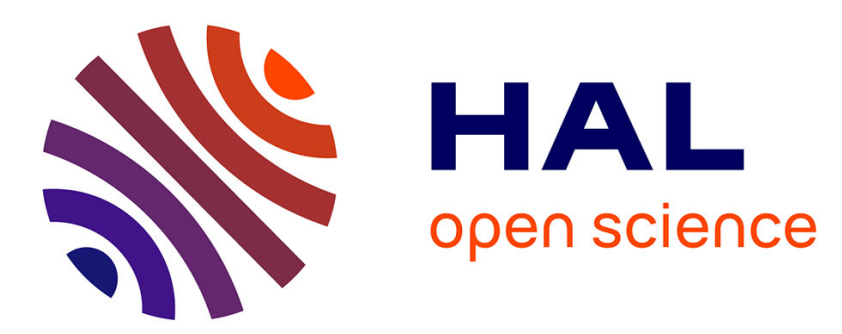

\title{
Medical and biological applications of multicolour laser
}

A. Izmailov, A. Ljutikov, A. Zhiglinskiy, N. Alexandrova, G. Kirillova, S.

Sosnihina

\section{To cite this version:}

A. Izmailov, A. Ljutikov, A. Zhiglinskiy, N. Alexandrova, G. Kirillova, et al.. Medical and biological applications of multicolour laser. Journal de Physique IV Proceedings, 1994, 04 (C4), pp.C4-203-C4206. 10.1051/jp4:1994448. jpa-00252711

\section{HAL Id: jpa-00252711 https://hal.science/jpa-00252711}

Submitted on 1 Jan 1994

HAL is a multi-disciplinary open access archive for the deposit and dissemination of scientific research documents, whether they are published or not. The documents may come from teaching and research institutions in France or abroad, or from public or private research centers.
L'archive ouverte pluridisciplinaire HAL, est destinée au dépôt et à la diffusion de documents scientifiques de niveau recherche, publiés ou non, émanant des établissements d'enseignement et de recherche français ou étrangers, des laboratoires publics ou privés. 


\title{
Medical and biological applications of multicolour laser
}

\author{
A.M. IZMAILOV, A.P. LJUTIKOV, A.G. ZHIGLINSKIY, N.N. ALEXANDROVA*, \\ G.A. KIRILLOVA* and S.P. SOSNIHINA*
}

Physics Research Institute, Optics Dept., Peterburg University, Russia

* Dept. of Genetics and Breading 198904, Ulianovskaia 1, St. Peterburg, Russia

\begin{abstract}
Conventional lasers possess several demerita for their medical and biological applications. For example they emit only a single wavelength usualy or have relatively sharp region of colour tuning. As a result in spite of wide application of lasers in biology and medicine the influence of spectral characteristics of the laser radiation to the results oftheir action on the vital objects is not investigated enough. Conventional lasers have also high coherency usualy which can lead in sore cases to undesierable side effects. Their light spot has" unpleasant for eyes and uncomfortable grain structure:

A new malticolour superbroadband dye laser is developed in this paper for biological and medical applications which permits to apoid these difficulties. Tris laser 3 radiation can be tuned inside sil the visible region of spectrum from $390 \mathrm{~nm}$ up to $720 \mathrm{~nm}$ ). This region can be shifted to the near UV or IR if it is necessary. Maltilinear emission of radiation is possible also with independently tunable lines. They can be placed inside mentioned spectral region in any desirable combination. Spectral width of these lines are operatable from $0.1 \mathrm{~nm}$ up to $300 \mathrm{~nm}$. Generation of a broad continuura ( up to $120 \mathrm{~nm}$ ) is possible also. Output beam is delivered to the sample by the fiber bundle, which is mixing all the wavelengths simultaneously emitted by the polychromatic laser. It is possible also to deliver the radiation of each wavelenght independently. Multielenent active medium of the polychromatic laser is pamped by comercial nitrogen laser, with output power $300 \mathrm{~kW}$. It can be also pumped by more powerful excimer laser or by UV-harmonica of solid state lasers. Repetition rate of the polychromatic dye laser depends on the repetition rate of pumping laser and can be from sinele pulses up to 25 pps without dye circulation. The possibility is shown experimentaly of multicolour lasine with higher repetition rates ( up to $12 \mathrm{kHz}$ ) when the active mediun is pumped by copper vaprur laser. The averse output power of the multicolour laser can be increased in this case up to $150 \mathrm{~mW}$.

So suggested laser permits to investigate ppectral dependencies of the laser zadiation action, to study possible sinergetical effects connected with simultaneous illumination of biological or medical object under investigation by radiation of different wavelengths or by radiation of various coherency.

Developed polychromatio dye laser is applied for investigetion of action of different wavelenghs radiation in a broad spectral region to the biological objects. Variation of growth was studied of unicellular green algae clamidomonas reinhardti and sprouts of barley Hordeun vigare. The spectral range used in these experiments was $440-670 \mathrm{~nm}$. The exposition of irradiation was varied from $5 * 10^{-3} \mathrm{~J} / \mathrm{cm}^{2}$ up to $2 \mathrm{~J} / \mathrm{cm}^{2}$.
\end{abstract}


The efficiency of mitotic devision of the first sporulation after illumination was measured for green algae Clamidomonas reinhardtii. An asinchronous culture of the shtamm 798-44a was used in these experiments. The sample with algae cells was illuminated by the radiation wich wavelengths were concorded with the absorbtion spectrun of water solution containing these cells. A value of mitotic index I was estimated in every experiment which shows the average number of cytokineses in the selection of the observed cells. The number of cells division was counted 24 hours after irradiation. Dependence of the relative value of mitotic index measured for these cells (related to the value in the control sample lo) on the exposition $p$ of laser irradiation for different wavelengths is shown in Fig. 1.

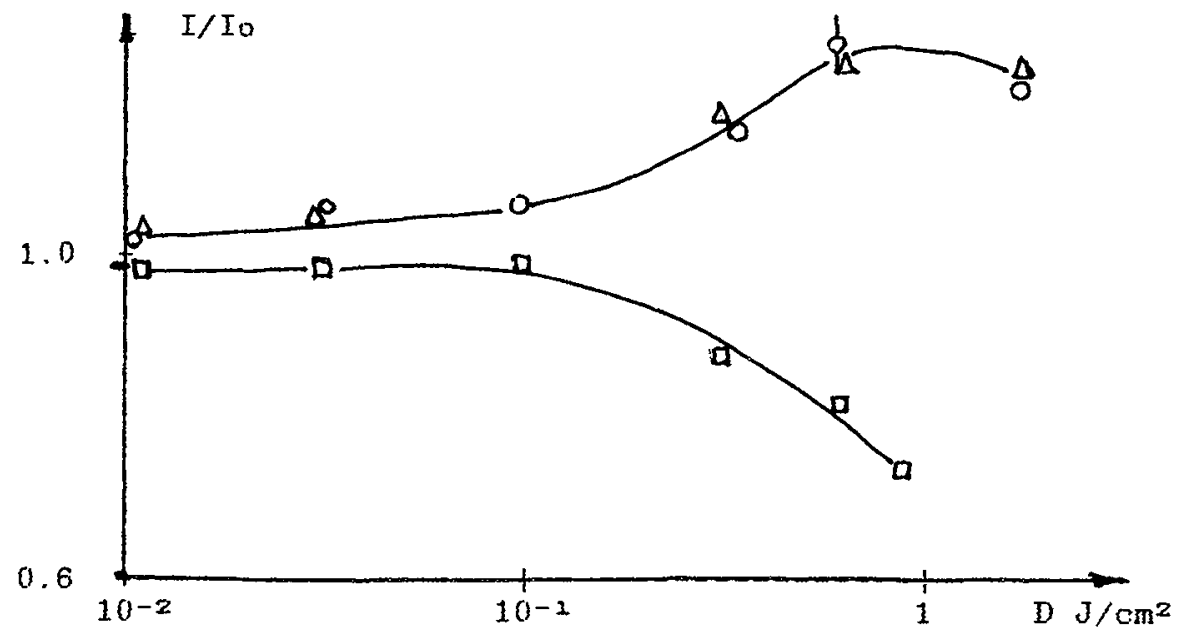

Fig.1. Variation of the mitotic index $I$ after irradiation of algae cells by different wavelength as a function of exposition $D$.

$$
\begin{aligned}
& 0 \text { - red light }(632 \mathrm{~nm}) \\
& \Delta-\text { green light }(530 \mathrm{~nm}) \\
& 0 \text { - blue light }(480 \mathrm{~nm})
\end{aligned}
$$

It can be seen, that noticeable change of mitotic index appears for the expositions above $0.1 \mathrm{~J} / \mathrm{cm}^{2}$. The result of the laser's radiation action depends on the wavelength ( compair curve 1 and 2 in Fig.1) and by its appropriate choose it is possible both to stimulate or decrease the growth of investigated biological object curve 1 for green and red light and curve 2 for blue light correspondingly.

Barley (Hordeum Vulgare) of a sort Pirck is used as a second object of investigation, because it was found out earlier that it is sensitive to the influence of chemicals on its changeability. The sensitivity of this barley was seen from increase of chromosome aberrations number in the rootlets meristeme and from a number of ear's morphoses appearing as a result action of different herbicides solutions effect on the young growth. So it was possible to suppose that it will be sensitive to the laser radiation also.

Rootlets of the young growth barley were illuminated so 
that neristeme cells of embryo were irradiated by the laser beam delivered from the polychromatio laser by the fiber. bundle. Part of the rootlets were fixed four hours after illumination according to Karnua ( in the solution containing 3 parts of ethanol and 1 part of vinegar acid) and coloured by acetolacmoid dye. The mitotic index mas estimated.

A number of samples from one rootlet was equal 1-3. The part of dividing tissue was studied. The full number of celle were taken in consideration and the number of deviding cells in meta-, ana-, and telophases were counted. The value of mitotic index was caloulated as a ratio of three last quantities to the full number of cells. The results for different rootlets were united, because they are homogeneous and a full number of cells inside each variant was sufficiently big (from 4000 up to 9000 ).

When the rootlets were illuminated by the conventional He-Ne laser with the exposition $0.3 \mathrm{~J} / \mathrm{cm}^{2}$ the mitotic index increased up to $6.9 \%$ and was 1.5 times higher than this value in the control sample. Three times higher exposition leads to decrease the mitotic index up to $3.3 \%$. These data are reliable $\left(X^{2}=28.2\right.$ and 12.7 correspondingly $)$. The results of data processing inside egch group of experiments differs moderately from each other ( $X^{2}=1.3$ and $X^{2}=1.2$ correspondingly). Irradiation of rootlets by the green light of dye laser with the exposition $0.3 \mathrm{~J} / \mathrm{cm}^{2}$ and $1 \mathrm{~J} / \mathrm{cm}^{2}$ decreased the number of cell divisions. Mitotic index was $1.4-1.7$ times lower than in control sample in both cases $\left(X^{2}=23.7\right.$ and $X^{2}=11.5$ for $0.3 \mathrm{~J} / \mathrm{cm}^{2}$ and $1 \mathrm{~J} / \mathrm{cm}^{2}$ correspondingly).

Simultaneously irradiation of rootlets by red and green light emitted by polychromatic dye laser leads to the decrease of mitotic index on the first stage, but it was increased up to the value of control sample for exposition $2 \mathrm{~J} / \mathrm{cm}^{2}$. The influence of red light may have a positive influence, compensating the suppression effect of the green light. The other rootlets were exposed on the humid cotton wool from 1 up 3 days at the room temperature. Then following physiological parameters were estimated: number and length of rootlets the velocity of their growth, the length of coleoptile of sprouts and an average number of deviding cells in the meristeme of roots. It was found out that for all the irradiated rootlets growth was higher than in control sample during first two days. This difference became more noticible up to 1.5 times after the third day. The most effectie action has a red light ( $630 \mathrm{~nm}$ ) and a mixture of red ( $630 \mathrm{~nm}$ ) and blue ( $480 \mathrm{~nm}$ ) radiation in this case.

It is possible to conclude that there is a stimulation action of the laser radiation on the investigated biological object. The increase of the effects discussed above can be expected in the analogous experiments for higer average power of irradiatiton, which is possible to get if polychromatic laser is pumped by a copper vapour laser, for example.

One of the dangers provisionaly existing in laser medicine is a probability of chromosome aberration appearence. It is necessary to investigate this problem carefully espessially in the case of pulse lasers application because of its higher intensity. Special analisys of irradiated cells did not show any chromosome aberrations in our case. 
Concirning to application of the multicolour laser in medicine, we can say, that developed laser possess following provisional advantages:

1. Different tissues have their own specific features in spectral dependency of light absorbtion. So the exact choose of light colour used for irradiation can increase the laser therapy efficiency. Developed laser is very broadband and has wide abbilities for appropriate choose of colours. The efficiency can be possibly hieher or the laser action can be less dangerous if to use simultaneously several wavelengths placed in correct spectral positions.

2. Polychromatic laser can emit the light with low ( or tunable) coherency. This decreases the probability of side effects.

3. Simultaneous radiation of $2-3$ different tunable colours used in microscopy and intrascopy gives an abbility to avoid the colour distortion of the object under investigation:

4. Emission of a continuum is possible with spectral distribution of output energy which is more appropriate for human being than that of traditional lasers with a sharp line. For example, radiation with spectrum alike that in sunlight can be simulated.

5. Superbroad multicolor radiation can be sucsessfuly used in medical laboratories, for example, in luminescence and absorbtion analysis and in other optical methods of diagnostics. According to literature data such lasers can increase the effeciency of laser application in oncology, cardiology, physiotherapy and so on. 